\title{
The Art of HIV Elimination: Past and Present Science
}

\author{
Collins C. Iwuji ${ }^{1,2,}$, Nuala McGrath ${ }^{1,3}$, Tulio de Oliveira ${ }^{1}$, Kholoud Porter $^{4}$, Deenan Pillay ${ }^{1,5}$, Martin Fisher ${ }^{6}$, Melanie Newport ${ }^{7}$ and Marie- \\ Louise Newell ${ }^{8}$ \\ ${ }^{1}$ Africa Centre for Health and Population Studies, University of KwaZulu Natal, South Africa \\ ${ }^{2}$ Research Department of Infection and Population Health, University College London, UK \\ ${ }^{3}$ Academic Unit of Primary Care and Population Sciences, and Department of Social statistics and Demography, University of Southampton, UK \\ ${ }^{4} \mathrm{MRC}$ Clinical Trials Unit at UCL, London, UK \\ ${ }^{5}$ Research Department of Infection and Immunity, University College London, UK \\ ${ }^{6}$ Division of Medicine, Brighton and Sussex Medical School, UK \\ ${ }^{7}$ Department of Infectious Diseases and Global Health, Brighton and Sussex Medical School, UK \\ ${ }^{8}$ Faculty of Medicine and Faculty of Social and Human Sciences, University of Southampton, UK
}

\begin{abstract}
Introduction: Remarkable strides have been made in controlling the HIV epidemic, although not enough to achieve epidemic control. More recently, interest in biomedical HIV control approaches has increased, but substantial challenges with the HIV cascade of care hinder successful implementation. We summarise all available HIV prevention methods and make recommendations on how to address current challenges.

Discussion: In the early days of the epidemic, behavioural approaches to control the HIV dominated, and the few available evidence-based interventions demonstrated to reduce HIV transmission were applied independently from one another. More recently, it has become clear that combination prevention strategies targeted to high transmission geographies and people at most risk of infections are required to achieve epidemic control. Biomedical strategies such as male medical circumcision and antiretroviral therapy for treatment in HIV-positive individuals and as preexposure prophylaxis in HIV-negative individuals provide immense promise for the future of HIV control. In resourcerich settings, the threat of HIV treatment optimism resulting in increased sexual risk taking has been observed and there are concerns that as ART roll-out matures in resource-poor settings and the benefits of ART become clearly visible, behavioural disinhibition may also become a challenge in those settings. Unfortunately, an efficacious vaccine, a strategy which could potentially halt the HIV epidemic, remains elusive.

Conclusion: Combination HIV prevention offers a logical approach to HIV control, although what and how the available options should be combined is contextual. Therefore, knowledge of the local or national drivers of HIV infection is paramount. Problems with the HIV care continuum remain of concern, hindering progress towards the UNAIDS target of $90-90-90$ by 2020 . Research is needed on combination interventions that address all the steps of the cascade as the steps are not independent of each other. Until these issues are addressed, HIV elimination may remain an unattainable goal.
\end{abstract}

Keywords: HIV; Combination HIV prevention; Antiretroviral therapy; Post-exposure prophylaxis; Pre-exposure prophylaxis; HIV vaccines; HIV cascade

\section{Introduction}

As the HIV epidemic approaches its fourth decade, effective prevention remains elusive in the communities most affected by the virus. An estimated 36.9 million people were living with HIV globally by end 2014 [1] of whom 70\% in sub-Saharan Africa. In 2014, an estimated 1.4 million people acquired HIV infection; $66 \%$ of these new infections and $66 \%$ of all HIV-related deaths occurred in sub-Saharan Africa, a region disproportionately affected by the epidemic. Remarkable strides have been made recently towards combating the epidemic and increasing antiretroviral therapy (ART) coverage with considerable reduction in mortality and morbidity [2], such that in $2014,40 \%$ of all people living with HIV were receiving ART. Following the results of the START [3] and TEMPRANO [4] trials, the World Health Organisation (WHO) now recommends ART regardless of CD4 count [5], a policy that would maximise both the individual and population health benefit of ART. This aligns with the recent UNAIDS target of 90:90:90 (90\% of people living with HIV aware of their HIV status, 90\% of people diagnosed HIV-positive on ART, $90 \%$ of people on ART virologically suppressed) in 2020 [6], but will require huge financial investments and commitments from governments to bear fruit.
It is now well-recognised that prevention approaches need to be combined to accelerate the effective prevention of HIV acquisition and transmissions [7]; HIV programme planning have now moved from the implementation of single preventive methods to combination contextspecific prevention approaches, for which evidence of effectiveness exists.

This paper reviews currently available HIV prevention methods, highlighting the strengths and weaknesses of past prevention approaches, draws attention to the present array of prevention armamentarium available and conceptualises how these could be combined towards the goal of HIV elimination.

*Corresponding author: Collins Chika Iwuji, Research Department of Infection and Population Health, University College London, UK and Africa Centre for Health and Population Studies, University of KwaZulu-Natal, P.O.Box 198, Mtubatuba 3935, South Africa, Tel: +27 355507500 ; E-mail: ciwuji@africacentre.ac.za

Received October 15, 2015; Accepted Novmeber 25, 2015; Published November 30, 2015

Citation: Iwuji CC, McGrath N, de Oliveira T, Porter K, Pillay D, et al. (2015) The Art of HIV Elimination: Past and Present Science. J AIDS Clin Res 6: 525 doi:10.4172/2155-6113.1000525

Copyright: ( 2015 Iwuji CC, et al. This is an open-access article distributed under the terms of the Creative Commons Attribution License, which permits unrestricted use, distribution, and reproduction in any medium, provided the original author and source are credited. 


\section{HIV Prevention}

\section{Behavioural prevention}

Behavioural prevention approaches include: delaying onset of first intercourse, decreasing the number of sexual partners, increasing the number of sexual acts protected, counselling and testing for HIV including repeat HIV testing, encouraging adherence to biomedical HIV prevention strategies, decreasing sharing of needles and syringes and reducing substance use [8].

A 2010 review of behavioural intervention trials, with HIV incidence as main outcome, showed no significant reduction in HIV incidence in any of the nine randomised-controlled trials studied [9]. Project Accept (HPTN 043), is a cluster-randomised trial evaluating whether a multicomponent social and behavioural prevention approach could reduce HIV incidence. In this trial community-based versus facilitybased HIV counselling and testing showed no significant reduction in HIV incidence overall (relative risk [RR] 0.86, 95\% CI 0.73-1.02) although there was a significant reduction in HIV incidence in he subgroup of women $>24$ years of age $(\mathrm{RR}=0.70,0 \cdot 54-0 \cdot 90)$ [10].

\section{Structural interventions}

HIV-associated structural factors are defined as the physical, social, cultural, organizational, community, economic, legal or policy aspects of the environment that impede or facilitate persons' efforts to avoid HIV infection [11] For example, laws that discriminate against certain HIV risk groups such as men who have sex with men (MSM) or injecting drug users may stigmatise and hinder access to HIV prevention services. Similarly, cultural norms which perpetuate gender inequity may leave women economically dependent on men and unable to negotiate condom use for fear of abandonment [12]. Interventions addressing these factors tend to be complex and context-specific; they do not seek to address risky behaviours directly, but address the prevailing circumstances which give rise to risky behaviours, acting on factors distal to the HIV outcome of interest. Distal factors may impact the outcome through multiple causal pathways making them difficult to evaluate; replication in other environments is challenging. One of the structural interventions receiving attention recently is the use of social cash transfers to encourage safer sex and a reduction in HIV acquisition. A randomised control trial in Lesotho using a lottery scheme as an incentive to reduce risky sexual behaviour showed a $25 \%$ (OR 0.75, 95\% CI 0.58 - 0.97) reduction in HIV incidence over 2 years [13]. A cluster randomised trial (CRT) in Malawi showed that cash incentives to young women and their households reduced HIV prevalence by $64 \%$ at 18 months; but making the payments conditional on school attendance made no difference to the reduction in HIV infection observed [14]. However a recently concluded CRT in South Africa showed that a conditional cash transfer to young women and men tied to HIV testing, participation in life skills training and academic attainment reduced the incidence of HSV-2 by $30 \%$ but did not have an impact on HIV incidence after 24 months [15]. Similarly, another recently concluded randomised trial in South Africa found that cash transfer which is conditional on $80 \%$ school attendance by young women showed no reduction in HIV incidence after 3 years [16]. These results suggest that the effectiveness of social cash transfer could be context specific.

\section{Treatment of sexually transmitted infections (STIs)}

Substantial evidence exists from observational studies suggesting an increased risk of HIV acquisition with both curable STIs and genital herpes $[17,18]$. STIs have also been associated with increased
HIV infectiousness, although this has not been quantified directly in observational studies [19]. HIV-STI co-infection appears more likely to result in HIV transmission than infection with HIV alone [20,21]

However, nine randomised trials to date (four cluster randomised trials, two individual randomised trials on treating curable STIs and three individual randomised trials on Herpes suppressive therapy) have together failed to confirm the hypothesis that STI treatment would reduce HIV transmission and acquisition [19]. Of the four cluster-randomised trials examining the impact of STI treatment on HIV incidence, only the Mwanza trial in Tanzania showed syndromic treatment of STIs to be associated with a $40 \%$ significant reduction in HIV incidence [22]. Various factors may explain the differences in effect between trials, including differences in the HIV epidemic phase, enhanced interventions in the control group, and higher prevalence of STIs in the Mwanza trial compared to the other sites [19].

Syndromic treatment of STIs focusses on patients presenting with symptoms, but provision of inadequate treatment and poor adherence could result in low effectiveness of syndromic treatment, which was estimated to be only $13 \%$ for curable STIs in rural KwaZulu-Natal [23]. Further, a significant proportion of STIs are asymptomatic [24] and the large pool of untreated individuals with asymptomatic STIs will continue to transmit HIV. This situation coupled with poor uptake of partner notification could result in significant rates of STI reinfections and will likely impact HIV transmission and acquisition.

The effect of herpes simplex virus (HSV) suppressive therapy on HIV incidence has been evaluated in two randomised trials; the first one in high-risk HSV-2 positive, HIV negative women in Tanzania [25] and the second involving women from three sites in Africa (Harare, Lusaka, Johannesburg) and MSM from Peru and the USA [26]. In these trials, treating HIV negative, HSV-2 positive individuals with aciclovir did not result in decreased HIV acquisition. A third randomised trial investigated the impact of HSV-2 suppressive therapy in HIV positive individuals on the risk of HIV transmission. Although suppressive therapy with acyclovir reduced HIV plasma viral load by about 0.25 $\log ^{10}$ and genital ulcers due to HSV-2 by $73 \%$, there was no significant effect on HIV transmission (RR 0.92, 95\% CI 0.60-1.41).

Although, these results are disappointing there remains compelling biological and epidemiological evidence that STIs are co-factors for HIV acquisition and transmission [27] and treatment of STIs should be part of the HIV care and prevention programme.

\section{Male circumcision}

A meta-analysis of 27 published observational studies on male circumcision in sub-Saharan Africa [28] provided evidence that male circumcision protects against HIV acquisition.

Male circumcision was shown to be protective against HIV acquisition in three randomised controlled trials in South Africa, Uganda and Kenya [29-31]; in pooled analysis the combined incidence risk ratio (IRR) at 12 months was 0.50 (95\% CI 0.34-0.72) and 0.46 (95\% CI $0.34-0.62)$ at 21 or 24 months [32].

These observations in heterosexual HIV acquisition raised the question of whether this protection would also be observed in MSM. However, an observational analysis of data from a randomised controlled trial of HSV-2 suppressive therapy to prevent HIV acquisition found no evidence that circumcision was associated with reduced HIV incidence in MSM who practised predominantly insertive sex (RR 0.31, 95\% CI: 0.06-1.51) [33] 
Citation: Iwuji CC, McGrath N, de Oliveira T, Porter K, Pillay D, et al. (2015) The Art of HIV Elimination: Past and Present Science. J AIDS Clin Res 6: 525. doi:10.4172/2155-6113.1000525

\section{Non-ART vaginal microbicides}

Initial research involving microbicides focused on non-ART related compounds, with a recent shift to ART-related compounds following multiple failures of the former to demonstrate effectiveness in the prevention of HIV acquisition in women.

These earlier compounds were surfactants (nonoxynol-9) which disrupt the cell membranes of bacteria and viruses, polyanions (Carraguard, cellulose sulphate and PRO 2000) which interfere with the attachment of the virus to target cells in the mucosa and vaginal milieu, and protectors (BufferGel) which render the vagina acidic. In an acidic environment, sperms and viruses are inactivated or killed [34]. A recent meta-analysis of 13 randomised controlled trials involving 35,905 HIV negative women from Africa, India, Thailand and the United States of America between 1996 -2011 showed no protective effects on HIV acquisition (RR 0.97, 95\% CI: 0.87-1.08) [35]. This meta-analysis included mostly non-ART related microbicides; five trials of nonoxynol-9, two trials of SAVVY, two of cellulose sulphate, one of Carraguard, one of PRO 2000 and one of BufferGel and one ART-related microbicide (CAPRISA 004 with 1\% vaginal tenofovir gel). More adverse events due to genital lesions were reported in the nonoxynol-9 trials while these events were similar in both the microbicide and placebo arms of the other trials.

\section{Antiretroviral treatment}

The efficacy of antiretroviral therapy at preventing HIV transmission has been demonstrated in a variety of clinical scenarios such as in the prevention of mother-to-child [36,37], and heterosexual transmission [38], which led to the declaration that an HIV infected individual who is on ART and has undetectable viral loads for at least 6 months with no STIs is sexually non-infectious [39]. Other uses include post-exposure prophylaxis in HIV-negative individuals after occupational or sexual exposure to body fluids from known or suspected HIV-positive individuals [40-43].

Oral and topical ART-based pre-exposure prophylaxis: More recently, studies have shown that ART could also be used by HIVnegative individuals prior to exposure to HIV to prevent HIV acquisition, known as pre-exposure prophylaxis (PrEP).

Table 1 summarises the 11 trials on pre-exposure prophylaxis using

\begin{tabular}{|c|c|c|c|c|c|c|c|}
\hline Author & Study setting & $\begin{array}{l}\text { Sample size } \\
\text { contributing } \\
\text { data }\end{array}$ & Study Population & Intervention/Control & $\begin{array}{l}\text { Follow-up } \\
\text { time/Person } \\
\text { years }\end{array}$ & HIV seroconversions & $\begin{array}{l}\text { Impact on HIV } \\
\text { incidence }(95 \% \mathrm{CI})\end{array}$ \\
\hline $\begin{array}{l}\text { Peterson, L } \\
2007[44]\end{array}$ & $\begin{array}{l}\text { Ghana, } \\
\text { Cameroun, } \\
\text { Nigeria }\end{array}$ & 936 & $\begin{array}{l}\text { 18-35 year old high risk } \\
\text { HIV negative women }\end{array}$ & $\begin{array}{l}\text { Intervention: Oral daily } \\
\text { tenofovir (TDF) Control: } \\
\text { Placebo }\end{array}$ & 476 & $\begin{array}{l}\text { Intervention: } 2 \\
\text { Control: } 6\end{array}$ & $\begin{array}{l}\text { Rate ratio (RR) } 0.35 \\
(0.03-1.93)\end{array}$ \\
\hline \begin{tabular}{|l|} 
Abdool Karim, Q \\
2010[45] (CAPRISA \\
004)
\end{tabular} & South Africa & 889 & $\begin{array}{l}\text { 18-40 year old HIV- } \\
\text { negative women }\end{array}$ & $\begin{array}{l}\text { Intervention: coitally } \\
\text { administered } 1 \% \text { vaginal } \\
\text { gel formulation of TDF } \\
\text { Control: Placebo }\end{array}$ & 1341 & $\begin{array}{l}\text { Intervention:38 } \\
\text { Control:60 }\end{array}$ & RR 0.61(0.40-0.94) \\
\hline $\begin{array}{l}\text { Grant RM, 2010[51] } \\
\text { (iPrEX study) }\end{array}$ & $\begin{array}{l}\text { Peru, Ecuador, } \\
\text { South Africa, } \\
\text { Brazil, } \\
\text { Thailand, USA }\end{array}$ & 2499 & $\begin{array}{l}\text { >18 years, HIV negative } \\
\text { MSM or transgender }\end{array}$ & $\begin{array}{l}\text { Intervention: Oral daily } \\
\text { tenofovir/emtricitabine } \\
\text { (TDF-FTC) } \\
\text { Control: Placebo }\end{array}$ & 3324 & $\begin{array}{l}\text { Intervention: } 36 \\
\text { Control: } 64\end{array}$ & $\begin{array}{l}44 \% \text { reduction } \\
(15-63)\end{array}$ \\
\hline $\begin{array}{l}\text { Thigpen MC, } \\
\text { 2012[52] (TDF2 } \\
\text { Study) }\end{array}$ & Botswana & 1219 & $\begin{array}{l}\text { 18-39 years, HIV negative } \\
\text { men and women }\end{array}$ & $\begin{array}{l}\text { Intervention: Oral daily } \\
\text { TDF-FTC } \\
\text { Control: Placebo }\end{array}$ & 1563 & $\begin{array}{l}\text { Intervention:9 } \\
\text { Control:24 }\end{array}$ & $\begin{array}{l}62.2 \% \text { reduction } \\
(21.5-83.4)\end{array}$ \\
\hline $\begin{array}{l}\text { Baeten J.M, } \\
\text { 2012[53] Partners } \\
\text { PrEP Study }\end{array}$ & Kenya, Uganda & 4747 & $\begin{array}{l}\text { Heterosexual HIV } \\
\text { serodiscordant couples }\end{array}$ & $\begin{array}{l}\text { Interventions: i) Once daily } \\
\text { oral TDF ii) Once daily } \\
\text { TDF-FTC } \\
\text { Control: Placebo }\end{array}$ & 7830 & $\begin{array}{l}\text { Interventions: TDF } 17 \\
\text { TDF/FTC: } 13 \\
\text { Control: } 52\end{array}$ & $\begin{array}{l}67 \% \text { reduction due } \\
\text { to TDF ( } 44-81) \\
75 \% \text { reduction due } \\
\text { to TDF/FTC (55-87) }\end{array}$ \\
\hline $\begin{array}{l}\text { Van Damme L, } \\
\text { 2012[46] FEM- } \\
\text { PrEP Study }\end{array}$ & $\begin{array}{l}\text { Kenya, } \\
\text { South Africa, } \\
\text { Tanzania }\end{array}$ & 2056 & $\begin{array}{l}18-35 \text { years, HIV negative } \\
\text { women }\end{array}$ & $\begin{array}{l}\text { Intervention: Oral daily } \\
\text { TDF-FTC } \\
\text { Control: Placebo }\end{array}$ & 1407 & $\begin{array}{l}\text { Interventions: } 33 \\
\text { Control: } 35\end{array}$ & $\begin{array}{l}\text { Hazard ratio (HR) } \\
0.94(0.59-1.52)\end{array}$ \\
\hline $\begin{array}{l}\text { Marrazzo J, } \\
\text { 2013[54] VOICE } \\
\text { Study }\end{array}$ & $\begin{array}{l}\text { South Africa, } \\
\text { Zimbabwe, } \\
\text { Uganda }\end{array}$ & 5029 & $\begin{array}{l}\text { Mean age } 25.3 \text { years, HIV } \\
\text { negative women }\end{array}$ & $\begin{array}{l}\text { Intervention: i) Oral daily } \\
\text { TDF ii)Oral daily TDF/FTC } \\
\text { iii) } 1 \% \text { TDF vaginal gel } \\
\text { Control: i) Oral placebo ii) } \\
\text { Placebo vaginal gel }\end{array}$ & 5509 & $\begin{array}{l}\text { Interventions: i) oral } \\
\text { TDF } 52 \text { ii) oral TDF- } \\
\text { FTC } 61 \text { iii) Vaginal TDF } \\
\text { gel: } 61 \\
\text { Control i) Placebo for } \\
\text { oral TDF: } 35 \\
\text { ii) Placebo for oral TDF/ } \\
\text { FTC: } 60 \text { iii) Placebo for } \\
\text { vaginal gel: } 70\end{array}$ & $\begin{array}{l}\text { HR for Oral TDF } \\
1.49(0.97-2.3) \\
\text { HR for oral TDF/ } \\
\text { FTC } 1.04(0.7-1.5) \\
\text { HR for vaginal TDF } \\
\text { gel } 0.85(0.6-1.2)\end{array}$ \\
\hline $\begin{array}{l}\text { Choopanya K, } \\
2013 \text { [55] Bangkok } \\
\text { Tenofovir study }\end{array}$ & $\begin{array}{l}\text { Bangkok, } \\
\text { Thailand }\end{array}$ & 2413 & $\begin{array}{l}20-60 \text { years, HIV negative } \\
\text { and reported injecting drug } \\
\text { use within the past year }\end{array}$ & $\begin{array}{l}\text { Intervention: Oral tenofovir } \\
\text { Control: Placebo }\end{array}$ & 9665 & $\begin{array}{l}\text { Intervention: } 17 \\
\text { Placebo: } 33\end{array}$ & $\begin{array}{l}\text { Efficacy of tenofovir } \\
48.9 \%(9.6-72.2)\end{array}$ \\
\hline $\begin{array}{l}\text { Rees H, } 2015 \\
\text { FACTS } 001\end{array}$ & South Africa & 2029 & $\begin{array}{l}\text { HIV negative women, } 18- \\
30 \text { years }\end{array}$ & $\begin{array}{l}\text { Intervention: Pericoital } 1 \% \\
\text { vaginal gel formulation of } \\
\text { Tenofovir } \\
\text { Control: Placebo }\end{array}$ & 3036 & $\begin{array}{l}\text { Intervention: } 61 \\
\text { Control: } 62\end{array}$ & IRR $1.0(0.7-1.4)$ \\
\hline $\begin{array}{l}\text { McCormack S, } \\
2015 \text { PROUD }\end{array}$ & England & 544 & $\begin{array}{l}\text { HIV negative MSM, } \geq 18 \\
\text { years }\end{array}$ & $\begin{array}{l}\text { Immediate: oral daily TDF/ } \\
\text { FTC } \\
\text { Deferred: Oral daily TDF/ } \\
\text { FTC after } 12 \text { months }\end{array}$ & 465 & $\begin{array}{l}\text { Immediate: } 3 \\
\text { Deferred: } 20\end{array}$ & $\begin{array}{l}86 \% \text { reduction } \\
(64-96)\end{array}$ \\
\hline $\begin{array}{l}\text { Molina J-M, } 2015 \\
\text { IPERGAY }\end{array}$ & $\begin{array}{l}\text { France, } \\
\text { Canada }\end{array}$ & 400 & HIV negative adult MSM & $\begin{array}{l}\text { Intervention: On demand } \\
\text { TDF/FTC } \\
\text { Control: Placebo }\end{array}$ & & $\begin{array}{l}\text { Intervention: } 2 \\
\text { Control: } 14\end{array}$ & $\begin{array}{l}86 \% \text { reduction } \\
(39.4-98.5)\end{array}$ \\
\hline
\end{tabular}

Table 1: Oral and ART-based topical pre-exposure prophylaxis. 
Citation: Iwuji CC, McGrath N, de Oliveira T, Porter K, Pillay D, et al. (2015) The Art of HIV Elimination: Past and Present Science. J AIDS Clin Res 6: 525. doi:10.4172/2155-6113.1000525

ART completed to date. The first trial evaluating the effectiveness of once daily oral tenofovir for pre-exposure prophylaxis was conducted in three sites in Ghana, Cameroun and Nigeria among high risk HIVnegative women aged 18-35 years [44]. The Nigeria and Cameroun sites were closed prematurely for unspecified reasons and as a result this trial lacked statistical power because of the small number of HIV seroconversions observed. In the CAPRISA 004, a proof-of-concept phase II trial including 889 HIV negative women, 1\% tenofovir gel compared to placebo was shown to significantly decrease HIV acquisition, (RR 0.63, 95\% CI 0.43-0.93) [45]. However, the results of three other PrEP trials, FEM-PrEP [46] , VOICE [47] and FACTS 001 [48] conducted in women have been very disappointing with none of them demonstrating any efficacy. Substudies of adherence within these large trials showed that there was poor adherence to the study drug which could explain the lack of efficacy observed.

The placebo arm of two other PreP trials - IPERGAY [49] and PROUD [50] - were terminated early because of marked reduction in HIV acquisition in the intervention arm compared to the placebo arm

ART in HIV-discordant partnerships: Table 2 summarises the nine observational studies and one randomised-controlled trial evaluating the effectiveness of ART in preventing HIV transmission from the index to the HIV-uninfected partner. A Cochrane review and meta-analysis [56] of these observational studies identified $2112 \mathrm{HIV}$ transmissions: 1,016 among ART-treated couple and 1096 in those not taking ART. The combined rate ratio for the nine observational studies was 0.58 (95\% CI: 0.17-0.75).

The one trial was a multicentre randomised-controlled trial (HPTN 052) [38] involving 1763 stable serodiscordant couples from 9 countries (Table 2) which reported findings in 2011. HIV infected individuals with CD4 counts between $350-550$ cells $/ \mu \mathrm{L}$ and in a stable relationship with an uninfected partner were randomly allocated to receive ART immediately (early therapy) or delayed until CD4 count decreased below 250 cells $/ \mathrm{mm}^{3}$ or development of clinical symptoms (deferred therapy). This study was stopped early because of clear efficacy of ART in preventing transmission in the early therapy arm. There were 39 HIV transmissions in total of which 28 were virologically linked to the infected partner; of the linked transmissions, 27 occurred in the deferred and one in the early therapy group (HR 0.04, 95\% CI: 0.01 0.27). Besides the clear public health significance of this finding, there was also a clinical benefit to the individual if randomised to the early therapy arm.

An earlier meta-analysis [57] reviewed observational studies of HIV transmission involving individuals on and not on ART from 11 cohorts comprising 5021 heterosexual couples and $461 \mathrm{HIV}$

\begin{tabular}{|c|c|c|c|c|c|c|c|}
\hline Author & Study setting & $\begin{array}{l}\text { No of } \\
\text { couples }\end{array}$ & Study population & $\begin{array}{l}\text { Study design/ } \\
\text { intervention }\end{array}$ & $\begin{array}{l}\text { Follow-up } \\
\text { duration in } \\
\text { person years }\end{array}$ & $\begin{array}{l}\text { ART status of } \\
\text { index case \&sero- } \\
\text { conversions }(n)\end{array}$ & $\begin{array}{l}\text { Effect estimate } \\
(95 \% \mathrm{CI})\end{array}$ \\
\hline $\begin{array}{l}\text { Musicco, M } \\
1994[62]\end{array}$ & Italy & 436 & $\begin{array}{l}\text { Female sexual } \\
\text { partners of HIV- } \\
\text { infected males } \\
\text { majority of whom were } \\
\text { injecting drug users }\end{array}$ & $\begin{array}{l}\text { Observational/ } \\
\text { Zidovudine (ZDV) } \\
\text { monotherapy }\end{array}$ & 740 & $\begin{array}{l}\text { Partners of men not on } \\
\text { ZDV: } 21 \\
\text { Partners of men on } \\
\text { ZDV: } 6\end{array}$ & $\begin{array}{l}\text { Risk lower in partners } \\
\text { of treated Men } \\
\text { RR } 0.50(0.1-0.9)\end{array}$ \\
\hline $\begin{array}{l}\text { Melo MG, } \\
2008[63]\end{array}$ & Brazil & 93 & $\begin{array}{l}\text { Female index case: } 67 \\
\text { Male index case: } 26\end{array}$ & $\begin{array}{l}\text { Observational/ } \\
41 \text { on triple ART } \\
52 \text { not on ART }\end{array}$ & Not stated & $\begin{array}{l}\text { Partner on ART: } 0 \\
\text { Partner not on ART : } 6\end{array}$ & $\begin{array}{l}\text { Risk lower if partner } \\
\text { on ART } \\
\text { RR } 0.10(0.01-1.67)\end{array}$ \\
\hline $\begin{array}{l}\text { Sullivan P, } \\
2009[64]\end{array}$ & Rwanda, Zambia & 2993 & $\begin{array}{l}\text { HIV discordant } \\
\text { couples }\end{array}$ & Observational & 5609 & $\begin{array}{l}\text { Partner on ART: } 4 \\
\text { Partner not on ART: } 171\end{array}$ & $\begin{array}{l}\text { Risk lower if partner } \\
\text { on ART } \\
\text { RR } 0.21(0.08-0.59)\end{array}$ \\
\hline $\begin{array}{l}\text { Del Romero, J } \\
\text { 2010[65] }\end{array}$ & Spain & 424 & Stable sexual couples & $\begin{array}{l}\text { Observational } \\
\text { *144 couples with index } \\
\text { partner on triple ART } \\
\text { * } 47 \text { couples on mono/dual } \\
\text { ART } \\
\text { *341 couples with index } \\
\text { partner not on ART }\end{array}$ & 1355 & $\begin{array}{l}\text { Partner on ART: } 0 \\
\text { Partner not on ART: } 5\end{array}$ & $\begin{array}{l}\text { Risk lower if partner } \\
\text { on ART } \\
\text { RR } 0.21(0.01-3.75)\end{array}$ \\
\hline $\begin{array}{l}\text { Donnell D, } \\
\text { 2010[66] }\end{array}$ & $\begin{array}{l}\text { Botswana, Kenya, } \\
\text { Rwanda, South } \\
\text { Africa, Tanzania, } \\
\text { Uganda, Zambia }\end{array}$ & 3381 & $\begin{array}{l}\text { HIV serodiscordant } \\
\text { partners }\end{array}$ & $\begin{array}{l}\text { Prospective cohort } \\
349 \text { initiated ART } \\
3082 \text { did not initiate ART }\end{array}$ & 4831 & $\begin{array}{l}\text { Partner on ART: } 1 \\
\text { Partner not on ART: } 102\end{array}$ & $\begin{array}{l}\text { Risk lower if partner } \\
\text { on ART } \\
0.08(0.00-0.57\end{array}$ \\
\hline Lu W, 2010[67] & China & 1927 & $\begin{array}{l}\text { HIV serodiscordant } \\
\text { couples } \\
\text { Male index } 1092 \\
\text { Female index } 835\end{array}$ & $\begin{array}{l}\text { Prospective cohort } \\
1369 \text { on ART } \\
558 \text { not on ART }\end{array}$ & 4918 & $\begin{array}{l}\text { Partner on ART: } 66 \\
\text { Partner not on ART: } 18\end{array}$ & RR 1.44 (0.85-2.44) \\
\hline $\begin{array}{l}\text { Reynolds SJ, } \\
\text { 2011[68] }\end{array}$ & Uganda & 250 & $\begin{array}{l}\text { HIV discordant } \\
\text { couples } \\
\text { Male index: } 145 \\
\text { Female index: } 155\end{array}$ & $\begin{array}{l}\text { Prospective cohort } \\
32 \text { initiated ART } \\
218 \text { not on ART }\end{array}$ & 513 & $\begin{array}{l}\text { Partner on ART: } 0 \\
\text { Partner not on ART: } 42\end{array}$ & RR 0.10 (0.01-1.64) \\
\hline $\begin{array}{l}\text { Cohen MS, } \\
\text { 2011[38] }\end{array}$ & $\begin{array}{l}\text { Botswana, Kenya, } \\
\text { Malawi, South } \\
\text { Africa, Zimbabwe, } \\
\text { Brazil, India, } \\
\text { Thailand, USA }\end{array}$ & 1763 & $\begin{array}{l}\text { Stable HIV-discordant } \\
97 \% \text { heterosexual }\end{array}$ & $\begin{array}{l}\text { Randomised controlled } \\
\text { Immediate versus deferred } \\
\text { ART }\end{array}$ & 3152 & $\begin{array}{l}\text { Early therapy: } 1 \\
\text { Deferred therapy: } 27\end{array}$ & RR $0.04(0.01-0.27)$ \\
\hline $\begin{array}{l}\text { Birungi J, } 2012 \\
{[69]}\end{array}$ & Uganda & 586 & $\begin{array}{l}\text { Serodiscordant } \\
\text { couples }\end{array}$ & $\begin{array}{l}348 \text { ART-eligible couples } \\
\text { initiated } \\
238 \text { not eligible for ART }\end{array}$ & $\begin{array}{l}\text { Median follow } \\
\text { up of } 1.3 \text { years }\end{array}$ & $\begin{array}{l}\text { ART group : } 9 \\
\text { Non-ART group: } 8\end{array}$ & RR 0.91 (0.38-2.20) \\
\hline Jia Z, 2012 [70] & China & 38,862 & $\begin{array}{l}\text { Serodiscordant } \\
\text { couples }\end{array}$ & $\begin{array}{l}24057 \text { ART-treated } \\
14,805 \text { non-ART group }\end{array}$ & 101,295 & $\begin{array}{l}\text { ART-group: } 935 \\
\text { ART-naïve: } 696\end{array}$ & RR $0.74(0.65-0.84)$ \\
\hline
\end{tabular}

Table 2: ART for preventing HIV transmission in HIV discordant partnerships. 
transmission events. The HIV transmission risk in the five studies of individuals on ART, irrespective of viral load, was 0.46 (95\% CI: 0.191.09) based on five transmissions and 1098 person years of follow up. When this meta-analysis was restricted to the two studies in which individuals had undetectable viral load, no transmission was recorded in 291 person years of follow up with an upper confidence limit of 1.27 per 100 person years.It is now established that ART is effective at preventing transmission in stable heterosexual couples, it remains unknown whether ART will be similarly effective at preventing HIV transmission at the population level. An observational study from rural KwaZulu-Natal suggests this to be the case [58]; and this question is currently being addressed by four randomised trials [59-61].

\section{HIV vaccines}

Recent HIV vaccine research has focused on antibody-based strategies following isolation of potent highly broadly neutralising monoclonal antibodies from infected individuals [71]. However, both arms of the adaptive immune system have important roles to play against HIV infection and or disease [71,72]. Neutralising antibody response aim to prevent acquisition of HIV infection, while cytotoxic $\mathrm{T}$ lymphocytes (CTL) response, which only recognises infected host cells, could play a role in controlling viral replication and disease progression. It is unclear if robust CTL response can eradicate HIV infection in humans [71].

Only one of the six HIV vaccine trials completed to date showed a protective efficacy (Table 3).

The VAX004 (North America and the Netherlands) and VAX003 (Thailand) were protein subunit trials using rgp120 monomers as immunogens aiming to elicit neutralising antibodies. Both failed to show significant protection against HIV acquisition [73,74].

Another vaccine approach is based on recombinant viral vectors engineered to express the gene of interest. The recombinant adenovirus serotype 5 was used as the vector for the Step (North and South America, the Caribbean and Australia) and Phambili (South Africa) trials $[75,76]$. These trials assessed the ability of these vaccines to stimulate the cellular immune responses. The Step trial was terminated early on the grounds of futility and lack of control of early viraemia in those who became infected. Enrolment in the Phambili trial was stopped because of the results observed in the Step trial.

The HVTN 505 (USA), was a phase 11b DNA vaccine trial that evaluated a DNA prime expressing Gag, Pol, Nef and Env with a recombinant adenovirus serotype 5 boost expressing Gag, Pol and Env. This trial was also halted prematurely for futility [77].
The RV144 vaccine trial in Thailand employed a combination of vaccine approaches [78], comprising a canary pox viral vector prime expressing Env, Gag and Pol followed by a protein subunit vaccine boost (AIDSVAX B/E). The vaccine efficacy was 31\% (95\% CI, 1.1 to 52.1 ) after 3.5 years. To date, this remains the only vaccine trial to demonstrate some protection against HIV acquisition.

\section{Mathematical modelling}

Mathematical modelling has played a pivotal role in the understanding of HIV pathogenesis by elucidating virus kinetics in terms of virus production and clearance from blood and CD4 T-lymphocytes depletion $[80,81]$. This showed that HIV replicated at a very rapid rate and demonstrated the superiority of combination therapy over single drug therapy on virus kinetics. This early models also examined the role of long-lived and latently infected cell populations in the blood and the question as to whether combination therapy would be adequate to eradicate or cure HIV in an individual arose as a hypothesis. Later models have identified third and fourth phase decays in HIV kinetics through the use of single copy assays [82]. This discovery as opposed to the initial two-phase decay proposed in earlier models implies that combination therapy may not be sufficient to eliminate HIV within an individual.

Models have also played significant roles in generating important hypothesis about the impact of immediate ART on HIV elimination from the general population. The model by Granich et al. [83] generated a lot of interest in this regard. This model predicted that yearly HIV testing followed by immediate ART coupled with male circumcision, behaviour change programmes, condoms and treatment of STIs could reduce HIV incidence to less than one case per 1000 per year within 10 years and reduce the prevalence of HIV to less than $1 \%$ within 50 years. However the assumptions used to parameterise the model may be overly optimistic as the impact of such approaches have been shown by more recent models to be sensitive to factors such as uptake of HIV testing, linkage to care and ART coverage and the nature of the sexual networks [84-86]. There are challenges in achieving the sort of coverage required as illustrated by the leaks in the HIV care cascade described below.

Mathematical models, in combination with empirical research would play pivotal role in understanding interventions and their expected impact on HIV prevention and elimination.

\section{Barriers to HIV Elimination}

\section{HIV care cascade}

For ART to succeed as an effective HIV prevention method, there

\begin{tabular}{|l|l|l|l|l|l|l|l|}
\hline Author & $\begin{array}{l}\text { Vaccine trial } \\
\text { (randomised-placebo } \\
\text { controlled }\end{array}$ & Vaccine type & Sample size & Population & Phase & $\begin{array}{l}\text { Intended immune } \\
\text { response }\end{array}$ & Results \\
\hline Flynn et al; 2005 [73] & VAX004 & Protein: rgp120 & 5400 & Mostly high-risk MSM & III \\
CD4+ T cells
\end{tabular}

Table 3: Summary of HIV vaccine trials and outcomes. 
needs to be good coverage in all the steps of the HIV care pathway. The entry point into this pathway is HIV testing. Those testing HIVpositive need to be willing to initiate ART even when not clinically indicated for their own health, retained in care and be adherent lifelong. Equally important are those who tested negative. They should be aware of methods to protect themselves from HIV acquisition and be willing to test for HIV repeatedly for those who become HIV-positive to be linked to the care pathway.

\section{HIV testing and linkage to care}

HIV testing is necessary for linkage to HIV care and treatment. For HIV elimination, large numbers of individuals have to be willing to test for HIV regularly and those testing positive need to be linked to care and started on ART. However, despite the availability of effective treatment for HIV, 36\% of individuals in SSA have never been tested for HIV [2], with low perception of risk, concerns about confidentiality and fear of disclosure, stigma and discrimination suggested as explanations. Gender inequity that leaves women economically dependent on men may undermine the ability of women to seek HIV testing [87-89].

Further, studies have shown a huge drop between the numbers of people taking an HIV test and linked to care. A systematic review and meta-analysis of eleven studies in SSA estimated that only $57 \%$ (95\% CI, 48-66) of those diagnosed HIV positive are linked to care [90]. Another meta-analysis of studies in the USA estimated that $69 \%$ (95\% CI, 66-71) of individuals diagnosed with HIV entered into care averaged over the time intervals from 1995 to 2009 [91]. Substantially higher numbers of individuals need to be linked to care for treatment assessment to realise the goal of HIV elimination. In a review of studies examining the barriers to linkage, the most commonly identified factors include transport costs and distance to clinics. Others include concerns about disclosure and stigma, staff shortages, long clinic waiting times, male sex and younger age [92].

\section{Adherence/Retention in Care}

The WHO defines adherence as "the extent to which a person's behaviour-taking medication, following a diet, and/or executing lifestyle changes, corresponds with agreed recommendations from a health care provider" [93]. Adherence to ART is vital for viral suppression [94], which is important for optimal treatment outcomes and for prevention of HIV transmission [95]. Studies reporting on routine treatment programmes with differing ART initiation CD4 thresholds have shown that individuals starting treatment at higher CD4 counts are less likely to adhere consistently than individuals starting at lower CD4 counts $[96,97]$. However in the HPTN 052 on stable sero-discordant couples, adherence measured by pill count of at least $95 \%$ was seen in $79 \%$ of participants in early therapy group (CD4 350-550 cells $/ \mathrm{mm}^{3}$ ) compared to $74 \%$ in the delayed therapy group $\left(\mathrm{CD} 4<250\right.$ cells $\left./ \mathrm{mm}^{3}\right)$ [38]. This may not be reflective of real life situations. It remains to be seen how evidence from the START [3] and TEMPRANO [4] trials which suggest individual benefit to early ART would influence adherence.

In the pre-exposure prophylaxis studies in which participants were aware that they were using the prescribed medications to prevent HIV transmission, adherence measured by drug levels was poor [46,54]. A meta-analysis involving 37 qualitative and 47 quantitative studies on barriers and facilitators to adherence identified fear of disclosure, concomitant substance abuse, forgetfulness, suspicions of treatment, complex regimens, high pill burden, decreased quality of life, work and family responsibilities, falling asleep and access to medications as the main adherence barriers [98]. Retention in HIV care takes two forms: pre-ART retention refers to retention in care of individuals not yet eligible for ART while retention on ART refers to individuals who remain in care after initiating ART. A review of four studies in South Africa and one in Malawi estimated that the median proportion of patients retained in pre-ART care was $45 \%$ when CD4 eligibility threshold was 200 cells $/ \mathrm{mm}^{3}$ [90]. A review of 14 studies reporting proportions of patients retained in care from ART eligibility to ART initiation estimates a median of $68 \%$ (range 14-84\%) [99]. For retention in care after initiating ART, a systematic review of 33 studies reporting on 39 patient cohorts estimated that $65 \%$ of patients are retained in ART care (range 58\%-72\%) after 36 months [100]. Factors that impact retention in care include challenges that relate to housing, transportation to clinics, mental health and drug abuse which would need to be addressed in affected individuals. Provider-patient relationship and clinic opening hours are other issues that need to be addressed to improve retention in care [91].

\section{Virological failure and drug resistance}

Initiation of treatment early in the course of infection before symptoms develop results in large proportions of HIV-infected individuals on ART; if adherence is indeed sub-optimal, this could lead to significant rates of virological failure and the likely development of drug resistance. Studies in sub-Saharan Africa of people who started treatment on the basis of conservative guidelines showed that $15-25 \%$ of patients had HIV-RNA $>400$ copies/mL 6-36 months after starting ART [101], consistent with findings from the Hlabisa HIV Treatment and Care programme with an estimated $15 \%$ of patients having HIV RNA $>400$ copies/mL 12 months after starting ART [102]. A further study from this latter cohort showed that $86 \%$ of individuals failing first-line ART with detectable VL had at least one drug-resistant mutation [103] with high levels of NNRTI- (83\%) and NRTI-(81\%) associated mutations; the median time spent on a failing regimen was 27 months (IQR 17-41). The long duration spent on failing ART with accumulation of resistant mutations could be a possible explanation for the $15 \%$ of patients with virological failurewhose second-line regimen was compromised.

With increasing exposure of larger numbers of people to longer durations of ART, those developing ART resistance could potentially transmit resistant virus to their sexual partners, which would result in increasing numbers of new infections due to resistant virus [104,105]. A recent evaluation of transmitted resistance in 11 regions in six subSaharan African countries including South Africa estimated prevalence of transmitted drug resistance in South Africa of $1.1 \%$, but $12.3 \%$ in Kampala, Uganda [106]. Increasing prevalence of transmitted resistance would necessitate more complex and more expensive firstline regimen which could impact on adherence and result in lack of virological suppression and increased transmissions making HIV elimination difficult.

\section{Risk compensation}

HIV has become a chronic condition, and some individuals may be less concerned about HIV than thirty years ago [107], which, coupled with the knowledge that ART may prevent HIV transmission, could lead to increased high risk sexual behaviour, known as risk compensation. However, studies in resource-limited settings with high HIV prevalence have not shown an increase in risky sexual behaviour amongst individuals initiating ART. In a Ugandan study, an increase in sexual activity following ART was accompanied by a 70\% reduction in the number of unprotected sexual acts with a partner known to be HIV negative or of unknown serostatus [108]. In a longitudinal study in 
South Africa on HIV-infected individuals with pre-ART and post-ART follow-up over seven years, high risk sexual behaviour following ART initiation was reduced [109]. A recent ecological study from a rural South African surveillance site found no evidence of an increase in high risk sexual behaviour at the population level following the expansion of ART availability, instead there was an increase in reported condom use at last sex with regular partners [110].

However, many studies in MSM in the developed world have shown an increase in high risk sexual behaviour following the introduction of ART coinciding with an increase in HIV incidence [111,112]. Whilst the frequency of HIV testing increased during this period, this was not sufficient to account for the observed increase in the number of new diagnoses [112].

As ART roll-out in sub-Saharan Africa is relatively recent, it is important to maintain on-going surveillance in risk behaviour in this region as this may change as more people become aware of the benefit of ART to prevent transmission.

\section{Conclusion}

Remarkable strides have been made in the past decade in potentially curbing the HIV epidemic, although numbers of new infections remain unacceptably high. No HIV prevention approach is $100 \%$ efficacious; all require behaviour change as individuals need to have the agency to decide which of the prevention methods best meet their needs at any particular point in time. The optimal way to tackle the epidemic is likely to be through combination HIV prevention [113,114], which combines behavioural change, treatment of STIs, ART for HIV positives and for pre-exposure prophylaxis for HIV negatives, male medical circumcision and structural approaches (Figure 1). It is now recognised that even within generalised epidemics, there are many microepidemics, hence interventions need to be focussed in nature by targeting areas of high transmission geographies and people at most risk of infections including key populations [115]

Which and how these interventions are combined may vary by setting using the "know your epidemic, know your response" concept
[116]. A modelling study calibrated using the Kenyan HIV epidemic showed that combination of interventions which are deployed in a focused manner as opposed to a uniform manner with a fixed budget applied to both scenarios resulted in more substantial decrease in the incidence of HIV infections [117]. This focused intervention approach requires that the HIV epidemic in a particular setting is characterised to subnational level.The partner demonstration project, which included high risk serodiscordant couples in Kenya and Uganda combined ART given to the HIV positive partner with PrEP given to the HIV negative partner resulted in a 96\% reduction in HIV transmission from the HIV positive to the HIV-negative partner.

Research is needed into how the cascade of care can be strengthened from the point of HIV testing to linkage of individuals to care and virological suppression. This would be necessary steps to maximise the impact the new WHO guidelines which recommend ART regardless of CD4 count [5].

Factors which act as barriers and facilitators for each step of the cascade need to be understood both at the individual and health care system level so that appropriate interventions can be put in place.

Novel drug formulations that require infrequent administration would be a welcome addition to the HIV prevention armamentarium, as this strategy has the potential to increase adherence [118].

Although the HIV vaccine field has been disappointing with no sufficiently efficacious vaccine currently available, lessons have been learnt from the research with improved insight as to how HIV evades the immune system. This is not the time to relax, rather to intensify efforts in this area because an efficacious preventive vaccine would be required in addition to other biomedical intervention in order to make HIV elimination an attainable goal. The vaccine efficacy required to achieve this would need to be modelled in combination with other prevention approaches [119]. Substantial investments with smart health-financing, integrating of health services and political commitment would be required to achieve the goal of HIV elimination [119].

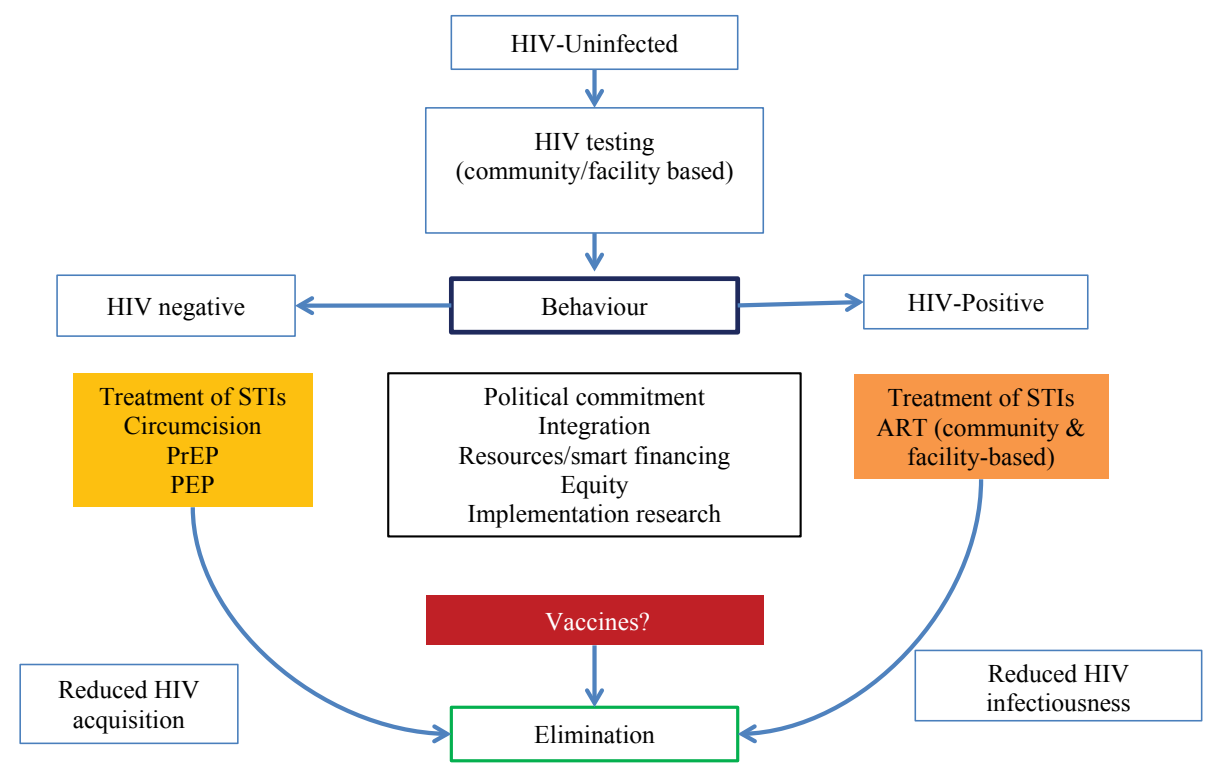

Figure 1: Combination interventions required to eliminate HIV. 
Citation: Iwuji CC, McGrath N, de Oliveira T, Porter K, Pillay D, et al. (2015) The Art of HIV Elimination: Past and Present Science. J AIDS Clin Res 6: 525. doi:10.4172/2155-6113.1000525

\section{Competing interests}

$\mathrm{Cl}$ has received honoraria for services rendered to Gilead Sciences. All other authors declare no competing interest.

\section{Acknowledgements}

I would like to acknowledge The French National Agency for Aids and Viral Hepatitis Research (ANRS) for funding the HIV treatment as Prevention trial within which my research is nested and the Africa Centre for Health and Population studies, University of KwaZulu-Natal for supporting my research at University College London. The Africa Centre for Health and Population Studies receives core funding from the Wellcome Trust, which provides the platform for the populationand clinic-based research at the Centre.

\section{Authors contributions}

$\mathrm{Cl}$ did the literature search and wrote the first draft of the review. NM, TDO $\mathrm{KP}, \mathrm{DP}, \mathrm{MF}, \mathrm{MN}$ and MLN extensively reviewed the article and made substantia contributions that improved the overall quality of the work. All the authors read and approved the final version of the manuscript.

\section{References}

1. UNAIDS (2015) How AIDS changed everything. MDG 6: 15 years, 15 lessons of hope from the AIDS response.

2. UNAIDS (2013) UNAIDS report on the global AIDS epidemic 2013.

3. INSIGHT START Study Group, Lundgren JD, Babiker AG, Gordin F, Emery $\mathrm{S}$, et al. (2015) Initiation of Antiretroviral Therapy in Early Asymptomatic HIV Infection. N Engl J Med 373: 795-807.

4. TEMPRANO ANRS 12136 Study Group, Danel C, Moh R, Gabillard D, Badje A, et al. (2015) A Trial of Early Antiretrovirals and Isoniazid Preventive Therapy in Africa. N Engl J Med 373: 808-822.

5. WHO (2015) Guideline on when to start antiretroviral therapy and on preexposure prophylaxis to ART.

6. UNAIDS (2014) 90-90-90 An ambitious treatment target to help end the AIDS epidemic.

7. Merson MH, O'Malley J, Serwadda D, Apisuk C (2008) The history and challenge of HIV prevention. Lancet 372: 475-488.

8. Coates TJ, Richter L, Caceres C (2008) Behavioural strategies to reduce HIV transmission: how to make them work better. Lancet 372: 669-684.

9. Ross DA (2010) Behavioural interventions to reduce HIV risk: what works? AIDS 24 Suppl 4: S4-14.

10. Coates TJ, Kulich M, Celentano DD, Zelaya CE, Chariyalertsak S, et al. (2014) Effect of community-based voluntary counselling and testing on HIV incidence and social and behavioural outcomes (NIMH Project Accept; HPTN 043): a cluster-randomised trial. Lancet Glob Health 2: e267-277.

11. Sumartojo E (2000) Structural factors in HIV prevention: concepts, examples, and implications for research. AIDS 14 Suppl 1: S3-10.

12. Gupta GR, Parkhurst JO, Ogden JA, Aggleton P, Mahal A (2008) Structura approaches to HIV prevention. Lancet 372: 764-775.

13. Björkman-Nyqvist M, Corna L, D de Walque, J Svensson (2013) Evaluating the Impact of Short Term Financial Incentives on HIV and STI Incidence Among Youth in Lesotho: A Randomised Trial. Sex Transm Infect 89: A325.

14. Baird SJ, Garfein RS, Mclntosh CT, Ozler B (2012) Effect of a cash transfer programme for schooling on prevalence of HIV and herpes simplex type 2 in Malawi: a cluster randomised trial. Lancet 379: 1320-1329.

15. Abdool Karim Q, Leask K, Kharsany A, Humphries $H$, Ntombela $F$, et al (2015) Impact of conditional cash incentives on HSV-2 and HIV prevention in rural South African high school students: results of the CAPRISA 007 cluster randomized controlled trial; abstract TUAC0101LB. in IAS. 2015. Vancouver.

16. Pettifor A (2015) HPTN 068 conditional cash transfer to prevent HIV infection among young women in South Africa: results of a randomized controlled trial. in IAS 2015. Vancouver.

17. Sexton J, Garnett G, Røttingen JA (2005) Metaanalysis and metaregression in interpreting study variability in the impact of sexually transmitted diseases on susceptibility to HIV infection. Sex Transm Dis 32: 351-357.

18. Glynn JR, Biraro S, Weiss HA (2009) Herpes simplex virus type 2: a key role in HIV incidence. AIDS 23: 1595-1598.
19. Hayes R, Watson-Jones D, Celum C, van de Wijgert J, Wasserheit J (2010) Treatment of sexually transmitted infections for HIV prevention: end of the road or new beginning? AIDS 24 Suppl 4: S15-26.

20. Deschamps MM, Pape JW, Hafner A, Johnson WD Jr (1996) Heterosexual transmission of HIV in Haiti. Ann Intern Med 125: 324-330.

21. Gray RH, Wawer MJ, Sewankambo NK, Serwadda D, Li C, et al. (1999) Relative risks and population attributable fraction of incident HIV associated with symptoms of sexually transmitted diseases and treatable symptomatic sexually transmitted diseases in Rakai District, Uganda. Rakai Project Team. AIDS 13: 2113-2123.

22. Grosskurth H, Mosha F, Todd J, Mwijarubi E, Klokke A, et al. (1995) Impact of improved treatment of sexually transmitted diseases on HIV infection in rural Tanzania: randomised controlled trial. Lancet 346: 530-536.

23. White RG, Moodley P, McGrath N, Hosegood V, Zaba B, et al. (2008) Low effectiveness of syndromic treatment services for curable sexually transmitted infections in rural South Africa. Sex Transm Infect 84: 528-534.

24. Peters RP, Dubbink JH, van der Eem L, Verweij SP, Bos ML, et al. (2014) Crosssectional study of genital, rectal, and pharyngeal Chlamydia and gonorrhea in women in rural South Africa. Sex Transm Dis 41: 564-569.

25. Watson-Jones D, Weiss HA, Rusizoka M, Changalucha J, Baisley K, et al. (2008) Effect of herpes simplex suppression on incidence of HIV among women in Tanzania. N Engl J Med 358: 1560-1571.

26. Celum C, Wald A, Hughes J, Sanchez J, Reid S, et al. (2008) Effect of aciclovir on HIV-1 acquisition in herpes simplex virus 2 seropositive women and men who have sex with men: a randomised, double-blind, placebo-controlled trial. Lancet 371: 2109-2119.

27. Fleming DT, Wasserheit JN (1999) From epidemiological synergy to public health policy and practice: the contribution of other sexually transmitted diseases to sexual transmission of HIV infection. Sex Transm Infect 75: 3-17.

28. Weiss HA, Quigley MA, Hayes RJ (2000) Male circumcision and risk of HIV infection in sub-Saharan Africa: a systematic review and meta-analysis. AIDS 14: $2361-2370$

29. Auvert B, Taljaard D, Lagarde E, Sobngwi-Tambekou J, Sitta R, et al. (2005) Randomized, controlled intervention trial of male circumcision for reduction of HIV infection risk: the ANRS 1265 Trial. PLoS Med 2: e298.

30. Bailey RC, Moses S, Parker CB, Agot K, Maclean I, et al. (2007) Male circumcision for HIV prevention in young men in Kisumu, Kenya: a randomised controlled trial. Lancet 369: 643-656.

31. Gray RH, Kigozi G, Serwadda D, Makumbi F, Watya S, et al. (2007) Male circumcision for HIV prevention in men in Rakai, Uganda: a randomised trial. Lancet 369: 657-666.

32. Siegfried N, Muller M, Deeks JJ, Volmink J (2009) Male circumcision for prevention of heterosexual acquisition of HIV in men. Cochrane Database Syst Rev: CD003362.

33. Sánchez J, Sal Y Rosas VG, Hughes JP, Baeten JM, Fuchs J, et al. (2011) Male circumcision and risk of HIV acquisition among MSM. AIDS 25: 519-523.

34. Ramjee G, Kamali A, McCormack S (2010) The last decade of microbicide clinical trials in Africa: from hypothesis to facts. AIDS 24 Suppl 4: S40-49.

35. Obiero J, Mwethera PG, Hussey GD, Wiysonge CS (2012) Vaginal microbicides for reducing the risk of sexual acquisition of HIV infection in women: systematic review and meta-analysis. BMC Infect Dis 12: 289

36. Connor EM, Sperling RS, Gelber R, Kiselev P, Scott G, et al. (1994) Reduction of maternal-infant transmission of human immunodeficiency virus type 1 with zidovudine treatment. Pediatric AIDS Clinical Trials Group Protocol 076 Study Group. N Engl J Med 331: 1173-1180.

37. Townsend CL, Cortina-Borja M, Peckham CS, de Ruiter A, Lyall H, et al. (2008) Low rates of mother-to-child transmission of HIV following effective pregnancy interventions in the United Kingdom and Ireland, 2000-2006. AIDS 22: 973-981.

38. Cohen MS, Chen YQ, McCauley M, Gamble T, Hosseinipour MC, et al. (2011) Prevention of HIV-1 infection with early antiretroviral therapy. N Engl J Med 365: 493-505.

39. Vernazza P, Hirschel B, Bernasconi E, Flepp M (2008) Les personnes séropositives ne souffrant d'aucune autre MST et suivant un traitement antirétroviral efficace ne transmettent pas le VIH par voie sexuelle. Bulletins des médecins suisses 89: 165-169. 
Citation: Iwuji CC, McGrath N, de Oliveira T, Porter K, Pillay D, et al. (2015) The Art of HIV Elimination: Past and Present Science. J AIDS Clin Res 6: 525. doi:10.4172/2155-6113.1000525

40. CDC (1995) Case-control study of HIV seroconversion in health-care workers after percutaneous exposure to HIV-infected blood--France, United Kingdom, and United States, January 1988-August 1994. MMWR Morb Mortal Wkly Rep 44: 929-933.

41. Schechter M, do Lago RF, Mendelsohn AB, Moreira RI, Moulton LH, et al. (2004) Behavioral impact, acceptability, and HIV incidence among homosexual men with access to postexposure chemoprophylaxis for HIV. J Acquir Immune Defic Syndr 35: 519-525

42. Drezzet J (2002) Post exposure prophylaxis in raped women, in IV Internationa Conference in HIV Infection in women and children. Rio de Janeiro: Livro de Resumos. Universidade, Federal do Rio De Janeiro e Institute of Virology of Maryland.

43. Harrison LH (2000) Demand for post-sexual-exposure chemoprophylaxis for the prevention of HIV infection in Brazil [abstract 492]. In 7th Conference on Retroviruses and Opportunistic Infections. 2000: San Francisco, California

44. Peterson L, Taylor D, Roddy R, Belai G, Phillips P, et al. (2007) Tenofovir disoproxil fumarate for prevention of HIV infection in women: a phase 2, doubleblind, randomized, placebo-controlled trial. PLoS Clin Trials 2: e27.

45. Abdool Karim Q, Abdool Karim SS, Frohlich JA, Grobler AC, Baxter C, et al. (2010) Effectiveness and safety of tenofovir gel, an antiretroviral microbicide, for the prevention of HIV infection in women. Science 329: 1168-1174.

46. Van Damme L, Corneli A, Ahmed K, Agot K, Lombaard J, et al. (2012) Preexposure prophylaxis for HIV infection among African women. N Engl J Med 367: 411-422.

47. Marrazzo JM, Ramjee G, Richardson BA, Gomez K, Mgodi N, et al. (2015) Tenofovir-based preexposure prophylaxis for HIV infection among African women. N Engl J Med 372: 509-518.

48. Helen Rees, Sinead A. Delany-Moretlwe, Carl Lombard, Deborah Baron, Ravindre Panchia, et al. (2015) FACTS 001 Phase III Trial of Pericoital Tenofovir $1 \%$ Gel for HIV Prevention in Women.

49. Jean-Michel Molina, Catherine Capitant, Bruno Spire, Gilles Pialoux, Christian Chidiac, et al. (2015) On Demand PrEP With Oral TDF-FTC in MSM: Results of the ANRS Ipergay Trial. Seattle, Washington.

50. McCormack S, Dunn DT, Desai M, Dolling DI, Gafos M, et al. (2015) Preexposure prophylaxis to prevent the acquisition of HIV-1 infection (PROUD): effectiveness results from the pilot phase of a pragmatic open-label randomised trial. Lancet.

51. Grant RM, Lama JR, Anderson PL, McMahan V, Liu AY, et al. (2010) Preexposure chemoprophylaxis for HIV prevention in men who have sex with men. N Engl J Med 363: 2587-2599.

52. Thigpen MC, Kebaabetswe PM, Paxton LA, Smith DK, Rose CE, et al. (2012) Antiretroviral preexposure prophylaxis for heterosexual HIV transmission in Botswana. N Engl J Med 367: 423-434.

53. Baeten JM, Donnell D, Ndase P, Mugo NR, Campbell JD, et al. (2012) Antiretroviral prophylaxis for HIV prevention in heterosexual men and women. N Engl J Med 367: 399-410.

54. Marrazzo JM, Ramjee G, Nair G, Palanee T, Mkhize B, et al. (2013) Preexposure prophylaxis for HIV in women: daily oral tenofovir, oral tenofovir/ emtricitabine or vaginal tenofovir gel in the VOICE study (MTN 003). 20th Conference on Retroviruses and Opportunistic Infections, Atlanta.

55. Choopanya K, Martin M, Suntharasamai P, Sangkum U, Mock PA, et al. (2013) Antiretroviral prophylaxis for HIV infection in injecting drug users in Bangkok, Thailand (the Bangkok Tenofovir Study): a randomised, double-blind, placebocontrolled phase 3 trial. Lancet 381: 2083-2090.

56. Anglemyer A, Rutherford GW, Egger M, Siegfried N (2013) Antiretroviral therapy for prevention of HIV transmission in HIV-discordant couples. Cochrane Database Syst Rev 4: CD009153

57. Attia S, Egger M, Müller M, Zwahlen M, Low N (2009) Sexual transmission of HIV according to viral load and antiretroviral therapy: systematic review and meta-analysis. AIDS 23: 1397-1404.

58. Tanser F, Bärnighausen T, Grapsa E, Zaidi J, Newell ML (2013) High coverage of ART associated with decline in risk of HIV acquisition in rural KwaZulu-Natal, South Africa. Science 339: 966-971.

59. Iwuji CC, Orne-Gliemann J, Tanser F, Boyer S, Lessells RJ, et al. (2013) Evaluation of the impact of immediate versus WHO recommendations-guided antiretroviral therapy initiation on HIV incidence: the ANRS 12249 TasP (Treatment as Prevention) trial in Hlabisa sub-district, KwaZulu-Natal, South Africa: study protocol for a cluster randomised controlled trial. Trials 14: 230.

60. Hayes R, Ayles H, Beyers N, Sabapathy K1, Floyd S, et al. (2014) HPTN 071 (PopART): rationale and design of a cluster-randomised trial of the population impact of an HIV combination prevention intervention including universal testing and treatment - a study protocol for a cluster randomised trial. Trials 15: 57.

61. AVAC, UNAIDS (2014) Antiretroviral Treatment for Prevention of HIV and Tuberculosis. 2013 update on current and planned research efforts.

62. Musicco M, Lazzarin A, Nicolosi A, Gasparini M, Costigliola P, et al. (1994) Antiretroviral treatment of men infected with human immunodeficiency virus type 1 reduces the incidence of heterosexual transmission. Italian Study Group on HIV Heterosexual Transmission. Arch Intern Med 154: 1971-1976.

63. Melo MG, Santos BR, De Cassia Lira R, Varella IS, Turella ML, et al. (2008) Sexual transmission of HIV-1 among serodiscordant couples in Porto Alegre southern Brazil. Sex Transm Dis 35: 912-915.

64. Sullivan P, Kayitenkore K, Chomba E, Karita E, Mwananyanda L, et al. (2009) Is the reduction of HIV transmission risk while prescribed antiretroviral therapy (ARVT) different for men and women? Results from discordant couples in Rwanda and Zambia. 5th IAS Conference on HIV Pathogenesis and Treatment Abstract no. WEAC101.

65. Del Romero J, Castilla J, Hernando V, Rodríguez C, García S (2010) Combined antiretroviral treatment and heterosexual transmission of HIV-1: cross sectional and prospective cohort study. BMJ 340: c2205

66. Donnell D, Baeten JM, Kiarie J, Thomas KK, Stevens W, et al. (2010) Heterosexual HIV-1 transmission after initiation of antiretroviral therapy: a prospective cohort analysis. Lancet 375: 2092-2098.

67. Lu W, Zeng G, Luo J, Duo S, Xing G, et al. (2010) HIV transmission risk among serodiscordant couples: a retrospective study of former plasma donors in Henan, China. J Acquir Immune Defic Syndr 55: 232-238.

68. Reynolds SJ, Makumbi F, Nakigozi G, Kagaayi J, Gray RH, et al. (2011) HIV-1 transmission among HIV-1 discordant couples before and after the introduction of antiretroviral therapy. AIDS 25: 473-477.

69. Josephine Birungi, Jeong Eun Min, Katherine A. Muldoon, Pontiano Kaleebu Rachel King, et al. (2012) Lack of effectiveness of antiretroviral therapy (ART) as an HIV prevention tool for serodiscordant couples in a rural ART program without viral load monitoring in Uganda. In XIX International AIDS Conference Washington, DC.

70. Jia Z, Mao Y, Zhang F, Ruan Y, Ma Y, et al. (2013) Antiretroviral therapy to prevent HIV transmission in serodiscordant couples in China (2003-11): a national observational cohort study. Lancet 382: 1195-1203.

71. Schiffner T, Sattentau QJ, Dorrell L (2013) Development of prophylactic vaccines against HIV-1. Retrovirology 10: 72.

72. Walker BD, Ahmed R, Plotkin S (2011) Moving ahead an HIV vaccine: use both arms to beat HIV. Nat Med 17: 1194-1195

73. Flynn NM, Forthal DN, Harro CD, Judson FN, Mayer KH, et al. (2005) Placebocontrolled phase 3 trial of a recombinant glycoprotein 120 vaccine to prevent HIV-1 infection. J Infect Dis 191: 654-665.

74. Pitisuttithum P, Gilbert P, Gurwith M, Heyward W, Martin M, et al. (2006) Randomized, double-blind, placebo-controlled efficacy trial of a bivalent recombinant glycoprotein 120 HIV-1 vaccine among injection drug users in Bangkok, Thailand. J Infect Dis 194: 1661-1671.

75. Buchbinder SP, Mehrotra DV, Duerr A, Fitzgerald DW, Mogg R, et al. (2008) Efficacy assessment of a cell-mediated immunity HIV-1 vaccine (the Step Study): a double-blind, randomised, placebo-controlled, test-of-concept trial. Lancet 372: 1881-1893.

76. Gray GE, Allen M, Moodie Z, Churchyard G, Bekker LG, et al. (2011) Safety and efficacy of the HVTN 503/Phambili study of a clade-B-based HIV-1 vaccine in South Africa: a double-blind, randomised, placebo-controlled test-of-concept phase $2 b$ study. Lancet Infect Dis 11: 507-515.

\section{NIH (2013) NIH Discontinues Immunizations in HIV Vaccine Study.}

78. Rerks-Ngarm S, Pitisuttithum P, Nitayaphan S, Kaewkungwal J, Chiu J, et al (2009) Vaccination with ALVAC and AIDSVAX to prevent HIV-1 infection in Thailand. N Engl J Med 361: 2209-2220.

79. Hammer SM, Sobieszczyk ME, Janes H, Karuna ST, Mulligan MJ, et al. (2013) 
Citation: Iwuji CC, McGrath N, de Oliveira T, Porter K, Pillay D, et al. (2015) The Art of HIV Elimination: Past and Present Science. J AIDS Clin Res 6: 525. doi:10.4172/2155-6113.1000525

Efficacy trial of a DNA/rAd5 HIV-1 preventive vaccine. N Engl J Med 369: 20832092.

80. Perelson AS, Nelson PW (1999) Mathematical analysis of HIV-1 dynamics in vivo. Siam Review 41: 3-44.

81. Ho DD, Neumann AU, Perelson AS, Chen W, Leonard JM, et al. (1995) Rapid turnover of plasma virions and CD4 lymphocytes in HIV-1 infection. Nature 373: 123-126.

82. Perelson AS, Ribeiro RM (2013) Modeling the within-host dynamics of HIV infection. BMC Biol 11: 96

83. Granich RM, Gilks CF, Dye C, De Cock KM, Williams BG (2009) Universa voluntary HIV testing with immediate antiretroviral therapy as a strategy for elimination of HIV transmission: a mathematical model. Lancet 373: 48-57.

84. Eaton JW, Johnson LF, Salomon JA, Bärnighausen T, Bendavid E, et al. (2012) HIV treatment as prevention: systematic comparison of mathematical models of the potential impact of antiretroviral therapy on HIV incidence in South Africa. PLoS Med 9: e1001245.

85. Dodd PJ, Garnett GP, Hallett TB (2010) Examining the promise of HIV elimination by 'test and treat' in hyperendemic settings. AIDS 24: 729-735

86. Hontelez JA, Lurie MN, Bärnighausen T, Bakker R, Baltussen R, et al. (2013) Elimination of HIV in South Africa through expanded access to antiretrovira therapy: a model comparison study. PLoS Med 10: e1001534.

87. McNairy ML, El-Sadr WM (2014) Antiretroviral therapy for the prevention of HIV transmission: what will it take? Clin Infect Dis 58: 1003-1011.

88. Musheke M, Ntalasha H, Gari S, McKenzie O, Bond V, et al. (2013)A systematic review of qualitative findings on factors enabling and deterring uptake of HIV testing in Sub-Saharan Africa. BMC Public Health 13: 220.

89. Deblonde J, De Koker P, Hamers FF, Fontaine J, Luchters S, et al. (2010) Barriers to HIV testing in Europe: a systematic review. Eur J Public Health 20 $422-432$

90. Kranzer K, Govindasamy D, Ford N, Johnston V, Lawn SD (2012) Quantifying and addressing losses along the continuum of care for people living with HIV infection in sub-Saharan Africa: a systematic review. J Int AIDS Soc 15: 17383

91. Marks G, Gardner LI, Craw J, Crepaz N (2010) Entry and retention in medica care among HIV-diagnosed persons: a meta-analysis. AIDS 24: 2665-2678.

92. Govindasamy D, Ford N, Kranzer K (2012) Risk factors, barriers and facilitators for linkage to antiretroviral therapy care: a systematic review. AIDS 26: 20592067.

93. WHO (2003) Adherence to long term therapies. Evidence for action.

94. Paterson DL1, Swindells S, Mohr J, Brester M, Vergis EN, et al. (2000) Adherence to protease inhibitor therapy and outcomes in patients with HIV infection. Ann Intern Med 133: 21-30.

95. Quinn TC, Wawer MJ, Sewankambo N, Serwadda D, Li C, et al. (2000) Vira load and heterosexual transmission of human immunodeficiency virus type 1. Rakai Project Study Group. N Engl J Med 342: 921-929.

96. Chi BH, Cantrell RA, Zulu I, Mulenga LB, Levy JW, et al. (2009) Adherence to first-line antiretroviral therapy affects non-virologic outcomes among patients on treatment for more than 12 months in Lusaka, Zambia. Int J Epidemiol 38: 746-756.

97. Maqutu D, Zewotir T, North D, Naidoo K, Grobler A (2010) Factors affecting first-month adherence to antiretroviral therapy among HIV-positive adults in South Africa. Afr J AIDS Res 9: 117-124.

98. Mills EJ, Nachega JB, Bangsberg DR, Singh S, Rachlis B, et al. (2006) Adherence to HAART: a systematic review of developed and developing nation patient-reported barriers and facilitators. PLoS Med 3: e438.

99. Rosen S, Fox MP (2011) Retention in HIV care between testing and treatment in sub-Saharan Africa: a systematic review. PLoS Med 8: e1001056.

100. Fox MP, Rosen S (2010) Patient retention in antiretroviral therapy programs up to three years on treatment in sub-Saharan Africa, 2007-2009: systematic review. Trop Med Int Health 15 Suppl 1: 1-15.

101. Harries AD, Zachariah R, van Oosterhout JJ, Reid SD, Hosseinipour MC et al. (2010) Diagnosis and management of antiretroviral-therapy failure in resource-limited settings in sub-Saharan Africa: challenges and perspectives. Lancet Infect Dis 10: 60-65.
102. Mutevedzi PC, Lessells RJ, Rodger AJ, Newell ML (2011) Association of age with mortality and virological and immunological response to antiretroviral therapy in rural South African adults. PLoS One 6: e21795.

103. Manasa J, Lessells RJ, Skingsley A, Naidu KK, Newell ML, et al. (2013) Highlevels of acquired drug resistance in adult patients failing first-line antiretrovira therapy in a rural HIV treatment programme in KwaZulu-Natal, South Africa. PLoS One 8: e72152.

104.Bennett DE, Myatt M, Bertagnolio S, Sutherland D, Gilks CF (2008) Recommendations for surveillance of transmitted HIV drug resistance in countries scaling up antiretroviral treatment. Antivir Ther 13 Suppl 2: 25-36.

105. Cambiano V, Bertagnolio S, Jordan MR, Pillay D, Perriëns JH, et al., (2014) Predicted levels of HIV drug resistance: potential impact of expanding diagnosis, retention, and eligibility criteria for antiretroviral therapy initiation. AIDS 28: S15-23.

106. Hamers RL, Wallis CL, Kityo C, Siwale M, Mandaliya K, et al. (2011) HIV-1 drug resistance in antiretroviral-naive individuals in sub-Saharan Africa after rollout of antiretroviral therapy: a multicentre observational study. Lancet Infect Dis 11: 750-759.

107. Scandlyn J (2000) When AIDS became a chronic disease. West J Med 172 130-133.

108. Bunnell R, Ekwaru JP, Solberg P, Wamai N, Bikaako-Kajura W, et al. (2006) Changes in sexual behavior and risk of HIV transmission after antiretroviral therapy and prevention interventions in rural Uganda. AIDS 20: 85-92.

109. Venkatesh KK, de Bruyn G, Lurie MN, Mohapi L, Pronyk P, et al. (2010) Decreased sexual risk behavior in the era of HAART among HIV-infected urban and rural South Africans attending primary care clinics. AIDS 24: 2687 2696.

110. McGrath N, Eaton JW, Bärnighausen TW, Tanser F, Newell ML (2013) Sexua behaviour in a rural high HIV prevalence South African community: time trends in the antiretroviral treatment era. AIDS 27: 2461-2470.

111. Katz MH, Schwarcz SK, Kellogg TA, Klausner JD, Dilley JW, et al. (2002) Impact of highly active antiretroviral treatment on HIV seroincidence among men who have sex with men: San Francisco. Am J Public Health 92: 388-394.

112. Bezemer D, de Wolf F, Boerlijst MC, van Sighem A, Hollingsworth TD, et al. (2008) A resurgent HIV-1 epidemic among men who have sex with men in the era of potent antiretroviral therapy. AIDS 22: 1071-1077.

113. Holmes KK (2007) King Kennard Holmes--chair of the Department of Global Health of The University of Washington. Interviewed by Marc Vandenbruaene. Lancet Infect Dis 7: 516-20.

114. UNAIDS (2010) Combination HIV Prevention:Tailoring and Coordinating Biomedical, Behavioural and Structural Strategies to Reduce New HIV Infections. A UNAIDS Discussion Paper.

115. Jones A, Cremin I, Abdullah F, Idoko J, Cherutich P, et al. (2014) Transformation of HIV from pandemic to low-endemic levels: a public health approach to combination prevention. Lancet 384: 272-279.

116. UNAIDS (2007) Practical guidelines for intensifying HIV prevention. Towards universal access.

117. Anderson SJ, Cherutich P, Kilonzo N, Cremin I, Fecht D, et al. (2014) Maximising the effect of combination HIV prevention through prioritisation of the people and places in greatest need: a modelling study. Lancet 384: 249 256.

118. Boffito M, Jackson A Owen A Becker S (2014) New approaches to antiretroviral drug delivery: challenges and opportunities associated with the use of long-acting injectable agents. Drugs 74: 7-13.

119. Piot P, Abdool Karim SS, Hecht R, Legido-Quigley H, Buse K, et al. (2015) Defeating AIDS--advancing global health. Lancet 386: 171-218. 